\title{
Maqasid Keamanan dan Implikasinya dalam Pembinaan Sebuah Tamadun
}

\section{Maqasid Peace and Its Implications for the Construction of a Civilization}

\author{
Muhammad Talhah Ajmain@Jimaain1, Wan Abdul Rahman Wan Ibrisam \\ Fiky $^{2}$, Aminuddin Ruskam ${ }^{3}$, Ahmad Kilani Mohamed ${ }^{4}$ \\ 1-4Universitas Teknologi Malaysia \\ Sultan Ibrahim Chancellery Building, Jalan Iman, 81310 Skudai, Johor, Malaysia \\ *corresponding author E-mail: mtalhah.uda@gmail.com
}

Diterima: 3 Maret 2020; Direvisi: 29 Maret 2020; Disetujui: 30 Maret 2020

\begin{abstract}
ABSTRAK
Maqasid perdamaian lahir dari kebutuhan untuk menjaga Maqasid Syariah dan keamanan lingkungan. Negara Islam yang menghadapi berbagai agama, ras dan etnis di Malaysia sangat membutuhkan konsep Perdamaian. Fiqh Maqasid ini untuk diimplementasikan untuk melindungi maslahah. Oleh karena itu, penelitian ini menggunakan metode kualitatif dengan "Tinjauan Pustaka" untuk merujuk ke perpustakaan lengkap. Studi ini melihat makna konsep Perdamaian Maqasid, pentingnya, argumennya dan dampak Maqasid pada pengembangan Peradaban. Penelitian ini menghasilkan Islam adalah agama yang didasarkan pada Al-Quran dan Sunnah. Tidak ada ajaran Islam yang menyerukan para pengikutnya untuk memancing permusuhan dan bahkan membawa kekacauan dan perang.
\end{abstract}

Kata kunci: Dampak, Keamanan Maqasid, Negara, Peradaban

\begin{abstract}
Maqasid peace was born from the need to maintain Maqasid Sharia and environmental security. An Islamic country that faces various religions, races and ethnicities in Malaysia desperately needs the concept of Peace. This Maqasid Fiqh is to be implemented to protect the maslahah. Therefore, this study uses a qualitative method with "Literature Review" to refer to the complete library. This study looks at the meaning of the concept of the Peace of Maqasid, its importance, its argument and the impact of Maqasid on the development of Civilization. This research resulted in Islam being a religion based on the Koran and the Sunnah. There are no Islamic teachings calling on his followers to provoke hostility and even bring chaos and war.
\end{abstract}

Keywords: Country, Civilization, Impact, Maqasid Security 
POLITICON : Jurnal Ilmu Politik Vol.2 No.1; Hal.1- 12

Website : http://journal.uinsgd.ac.id/index.php/politicon

ISSN : 2685-6670 ( Online )

\section{PENDAHULUAN}

Keragaman adalah sunnatullah dalam penciptaan makhluk. Hanya mereka yang memiliki kekuatan aqliah yang bisa merespons dengan baik (Bakar, 2017). Kekuatan keberagaman tidak bisa mengubah aturan Sunni oleh partai-partai berpengaruh dan menyebut diri mereka kekuatan dunia. Manusia tetap beragam dalam warna, agama, budaya dan bahasa seperti yang terkandung dalam pesan Al-Quran dalam surah al-Hujurat ayat 13 :

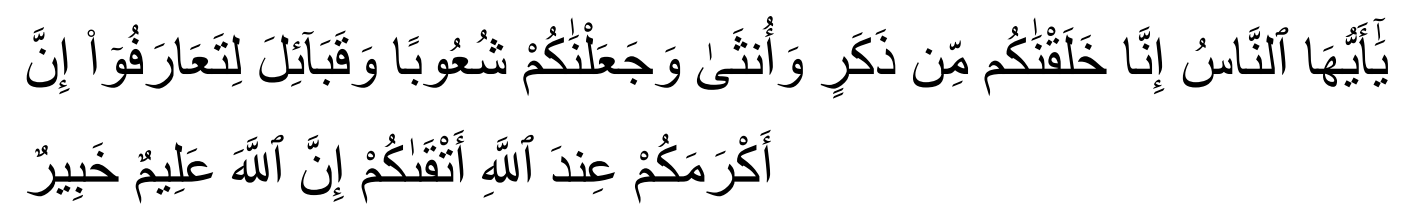

Karena itu, keberagaman yang mengekspresikan perbedaan harus disambut dan positif karena fenomena kemanusiaan - bangsa tersebut mengandung kearifan Ilahiyyah yang tersirat dalam kata-kata satu sama lain. Kata-kata li ta'arafu memiliki makna yang saling menguntungkan, yaitu untuk saling mengakui, menghargai satu sama lain, saling membantu dan bekerja sama untuk kebaikan dan sebagainya.

Salah satu mekanisme yang dapat dibahas untuk mewujudkan gagasan tersebut adalah memahami kehidupan bersama dalam keragaman dan perbedaan melalui apa yang disebut al-ta`ayusy atau ko-eksistensi. Bahkan diskusi tentang konsep ini telah dan sedang berlangsung di antara para sarjana, apakah itu melibatkan interaksi Muslim di negara-negara Muslim dengan komposisi ras yang beragam seperti di Malaysia atau interaksi Muslim sebagai minoritas di negara-negara non-Muslim. Arah diskusi secara umum adalah ingin menciptakan keharmonisan di negara dengan banyak ras, ras dan agama.

Studi ini menguraikan tiga tujuan utama untuk dicapai: 1. Memahami konsep Keamanan Maqasid 2. Ketahui argumen tentang perdamaian Mqosid 3. Identifikasi pentingnya dan implikasi dari perdamaian Maqasid pada peradaban.

Menurut Muhammad Mokhtar Gomaa Mabruk (2015) di masa 
POLITICON : Jurnal Ilmu Politik Vol.2 No.1; Hal.1- 12

Website : http://journal.uinsgd.ac.id/index.php/politicon

ISSN : 2685-6670 ( Online )

keragaman agama, ideologi, dan aliran atau orientasi intelektual yang besar, hal terpenting untuk memastikan stabilitas suatu masyarakat adalah kesediaan warga negara untuk hidup damai dengan sesama warga negara meskipun berbeda keyakinan dan praktik keagamaan. Keragaman ini adalah fitur dan mengandung nilai-nilai universal yang sejalan dengan firman Allah SWT yang disebutkan sebelumnya.

Kurangnya kesadaran akan pentingnya hidup bersama di komunitas multiras dan agama dapat berkontribusi pada kurangnya toleransi dalam kehidupan komunitas. Ini karena dunia saat ini sangat membutuhkan toleransi yang efektif dan koeksistensi positif antara manusia, serta hubungan positif antara budaya dan interaksi dan interaksi antar peradaban meningkat dari hari ke hari.

فقه التعايش Di antara dasar-dasar metode konsistensi dalam konteks yang dinyatakan oleh Hussein Ali Mustapha dalam (Leonard, 2015) ialah: 1Keunikan manusia - esensi dari ciptaan manusia yang diciptakan oleh lingkungan nasional, etnis dan geografis. 2- Islam menghormati keunikan masing-masing negara dengan bersikap positif dengan syarat bahwa itu tidak memungkinkan para pihak untuk mengambil keuntungan dari orang lain dan tidak membentuk garis pemisah yang menyatukan masing-masing kategori orang. 3- Islam menekankan bahwa keragaman keunikan manusia adalah simbol dari keanekaragaman pengalaman ilmiah dan praktis, dan bahkan apa yang membuat mereka berkenalan internasional yang memperkaya setiap negara.

Menurut al-Gharyani (2006), salah satu fondasi kunci dalam pembentukan fiqh al-ta ayusy adalah kesetaraan kemanusiaan, keadilan dan penolakan terhadap segala ketidakadilan, kebebasan beragama, yaitu, nonMuslim bebas mengadopsi Islam atau tetap beragama. mereka memenuhi janji, toleransi, keamanan ekonomi dan dapat berkontribusi pada administrasi negara.

Namun, dalam pendapat al-Tuwaijiri (2015), al-Ta’ayusy dalam 
POLITICON : Jurnal Ilmu Politik Vol.2 No.1; Hal.1- 12

Website : http://journal.uinsgd.ac.id/index.php/politicon

ISSN : 2685-6670 ( Online )

konteks keberagaman agama harus didasarkan pada empat hal, yaitu, tidak ada unsur paksaan, saling pengertian tentang tujuan semua pihak untuk saling menguntungkan, saling membantu sesuatu yang dapat dibagikan bersama untuk mencapai tujuan yang ditetapkan dan membangun rasa saling menghormati satu sama lain. Oleh karena itu, dalam mengatasi masalah keragaman ras dan etnis di suatu negara yang berupaya mencapai peradaban, perlu untuk merujuk pada sumber-sumber utama, yaitu nas dan argumen penjelasan, dan untuk mengetahui pentingnya serta dampak dari implementasinya. Sehingga dibutuhkan Fiqh atau Maqasid yang jelas yang dapat memberikan pedoman untuk mencapai keamanan Maqasid.

\section{METODE PENELITIAN}

Penelitian ini menggunakan metode pendekatan kualitatif (Sugiyono, 2013) serta melakukan pencarian data memalui studi dokumentasi dan kajian-kajian literatur yang sudah ada. Proses penelitian ini dimulai dari menyusun data-data yang didapat dengan aturan berpikir yang telah dibuat dalam penelitian. Penelitian ini menekankan pada makna, penalaran, definisi serta berdasarkan dari ayat-ayat suci al-Qur'an. Menggunakan tafsir tematik untuk memperdalam analisis pada setiap permasalahan yang dikemukakan, Tafsir Tematik merupakan cara yang dilakukan peneliti dengan seorang peneliti mengamati ayat - ayat Alquran yang memiliki satu tema kemudian Ayat - ayat tersebut disusun sedemikian rupa sehingga terstruktur dan sistematis untuk kemudian dipahami dari berbagai sudut pandang (Hidayatulloh, 2018).

\section{TEMUAN DAN PEMBAHASAN}

\section{MAQASID KEAMANAN}

Maqasid berasal dari kata maqsad atau qasd dalam arti yang sama dan berasal dari kata qasada yang berarti perjalanan yang layak (Fairuzabadi, 2007). Dalam hal istilah, Ibn 'Ashur (2018) mendefinisikan maqasid sebagai makna dan kebijaksanaan yang diwujudkan oleh al-syari' (Allah swt) dalam semua tasyri' atau sebagian besar yang tidak ditemukan hanya di bagian- 
POLITICON : Jurnal Ilmu Politik Vol.2 No.1; Hal.1- 12

Website : http://journal.uinsgd.ac.id/index.php/politicon

ISSN : 2685-6670 ( Online )

bagian tertentu dari hukum. hanya syariah.

Sementara itu, Allal al-Fasi (2017) mendefinisikannya sebagai tujuan, tujuan, dan rahasia yang ditetapkan oleh Syariah dalam setiap aturannya (syariah). Makna yang berbeda ini masih memiliki makna yang sama dengan maksud, tujuan, visi atau misi pengamanan dalam mengamankan dan melestarikan kesejahteraan manusia di dunia dan di akhirat (Masruri, 2016).

Menurut Abdullah bin Bayyah (1999), perdamaian adalah elemen penting dari kemanusiaan. Dengan demikian, ia mengaitkan konsep perdamaian dengan lima kebajikan dalam maqasid syariah utama yang merupakan pelestarian agama, kehidupan, kecerdasan, properti, dan keturunan. Peduli dengan lima hal ini akan menghasilkan kedamaian.

Menurut Al-Raghib al-Asfahani (1992) asal usul tujuan atau perdamaian al-amn adalah pengendalian diri dan hilangnya rasa takut. Keamanan adalah salah satu konsep kehidupan yang paling penting yang telah dibicarakan sejak lama dan berkembang pesat setelah peristiwa September 2011 (Rahim, Ramli, \& Zulkepli, 2018).

Terorisme agama dan terorisme sering memberi citra buruk pada agama dan para pengikutnya (arsyad, 2019). Dengan demikian, para sarjana kontemporer telah berupaya mewujudkan gagasan-gagasan keamanan dan perdamaian untuk menggantikan kekejaman, kekerasan, dan terorisme. Perdamaian juga sering dibahas dan dibahas panjang lebar oleh negara-negara dengan beragam kelompok agama, ras dan etnis. Perdamaian dalam konteks ini juga dapat dikaitkan dengan "perjanjian yang menyetujui perdamaian antara negara-negara yang bertikai", sebuah perjanjian yang menyetujui perdamaian antara negara-negara yang bertikai.

Di antara tokoh-tokoh terkemuka dalam tema perdamaian adalah Abdullah bin Bayyah (1999) dengan bukunya yang berjudul Khitab al-Amn fi alIslam wa Thaqafatu al-Tasamuh wa al-Wi'am. Selain itu, Yusof al-Qaradhawi (Al-Qaradawi, 2009) menulis sebuah buku berjudul fiqh al-Jihad yang menjelaskan arti sebenarnya dari jihad dan kesalahpahaman yang telah 
POLITICON : Jurnal Ilmu Politik Vol.2 No.1; Hal.1- 12

Website : http://journal.uinsgd.ac.id/index.php/politicon

ISSN : 2685-6670 ( Online )

membawa banyak orang ke ekstremisme dan terorisme. Baru-baru ini, Ketua Serikat Cendekiawan Islam Dunia Ahmad al-Raisuni menerbitkan sebuah makalah berjudul Maqasid al-Salam fi Syariah al-Islam yang menggambarkan pentingnya perdamaian dan tujuan perdamaian dalam Syariah (Azhar, Othman, Hussain, \& Md Nor, 2017).

Selain itu, Ali Muhyiddin al-Qaradaghi juga menghasilkan sebuah buku yang menjelaskan perdamaian yang dibawa oleh Islam dan bagaimana berinteraksi dengan non-Muslim. Di antara bukunya adalah Nahnu wa alAkhar dan Islam al-Rahmah wa Zhahirah al-Irhab dan Fiqh Al-Mizan (2019). Ali Jum'ah (2018) juga telah menulis beberapa buku tentang perdamaian dan harmoni di antara orang-orang tanpa memandang ras, agama dan negara. Di antara mereka adalah al-Jihad fi al-Islam dan al-Ta'ayush ma'a al-Akhar fi Dhoui al-Sirah al-Nabawiyyah: al-Usus wa al-Maqasid. Munculnya begitu banyak tulisan dan karya pada konsep koeksistensi, perdamaian, perdamaian adalah tulang punggung perang, perselisihan, dan kerusuhan yang terjadi di seluruh dunia. Ketika manusia mencari solusi terbaik untuk mengakhiri semua polemik keruntuhan ini, ada cendekiawan dan cendekiawan yang berusaha mendidik masyarakat tentang keamanan massa. Maqasid perdamaian adalah cabang ilmu maqasid Syariah yang menekankan pentingnya Syariah dalam melestarikan dan melestarikan keamanan universal. Konsep hidup berdampingan secara damai atau dalam bahasa Arabnya "al-Ta'ayush al-Silmi" adalah landasan pencapaian maqasid perdamaian.

\section{DALIL BERKAITAN MAQASID KEAMANAN}

Terdapat beberapa dalil yang menjadi asas kepada maqasid keamanan. Antaranya ialah (Al-Raisuni, 2018) :

1. Firman Allah dalam surah al-Baqarah ayat 208;

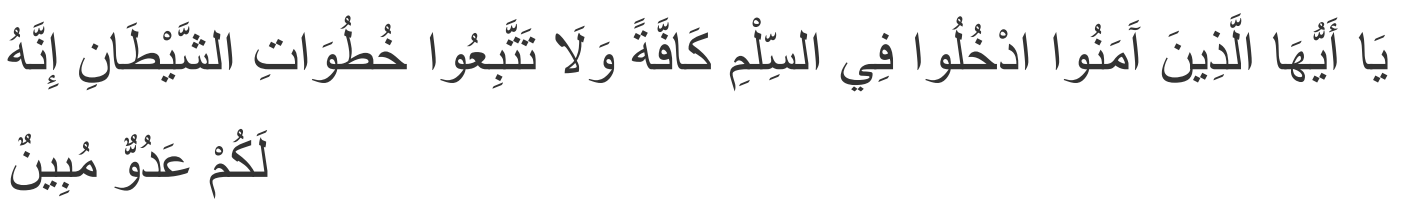

Menurut para mufassirun, perkataan al-silm dalam ayat di atas bermaksud agama Islam. Agama Islam adalah agama yang sentiasa membawa 
kepada kesejahteraan dan keamanan.

2. Surah al-Anfal ayat 61;

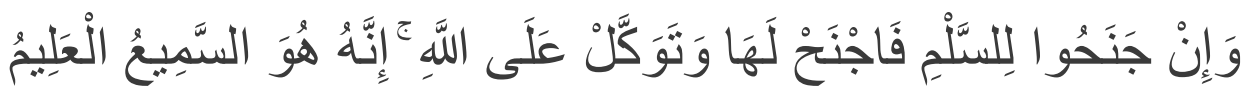

Ayat ini jelas menyuruh kepada perdamaian. Perdamaian yang membawa maksud lawan bagi permusuhan atau peperangan.

3. Surah an-Nisa' ayat 90 ;

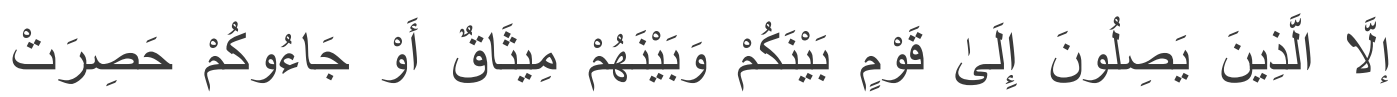

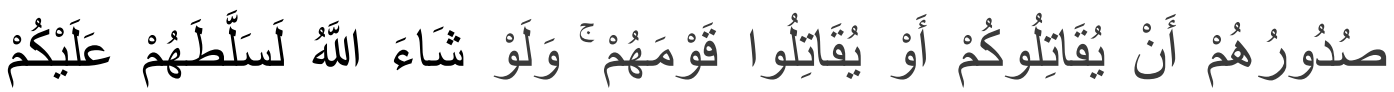

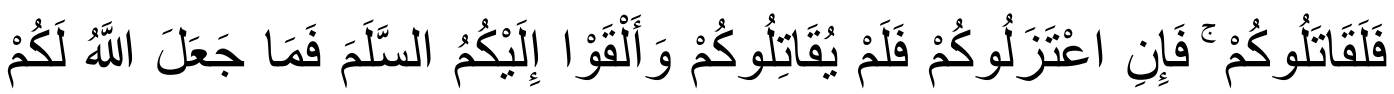

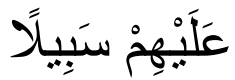

4. Surah an-Nisa' ayat 94 ;

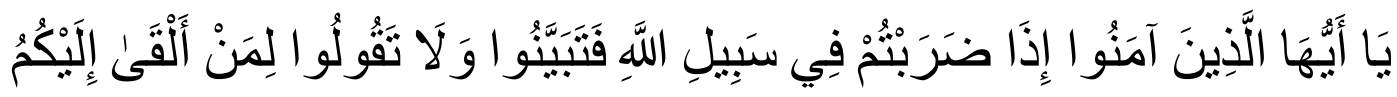

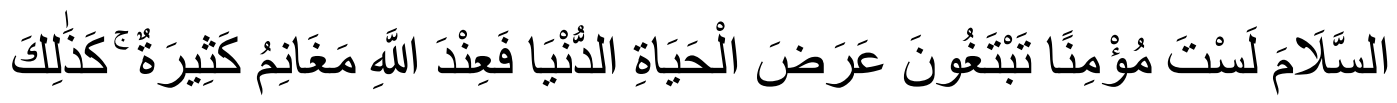

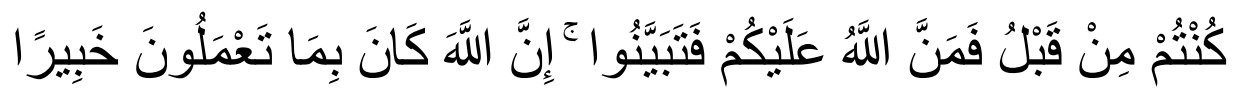

5. Dalam sirah Nabi Muhammad SAW, dia menunjukkan kesabaran dan ketekunan dalam menghadapi setiap cobaan dan tantangan, termasuk semua ancaman Mekah. Para sahabat pernah meminta Nabi Muhammad untuk membalas semua yang menimpa kaum Muslim tetapi dia menolak.

6. Nabi Muhammad SAW turut melakukan mengejar perdamaian dengan menandatangani perjanjian dengan orang-orang Yahudi di Madinah yang disebut konstitusi Madinah (Sahifah Madinah). Inti dari perjanjian ini adalah gencatan senjata di kedua sisi.

7. Nabi Muhammad SAW juga setuju untuk berdamai dengan para biarawan Mekah ketika ia menandatangani perjanjian Hudaibiyah (Sulh al-Hudaibiyah) dengan para rahib Mekah setelah menyebarkan berita kematian 'Utsman bin' Affan yang adalah seorang nabi ke Mekah untuk bertemu dengan orang-orang Mekah Mekah untuk menyampaikan keinginan umat Islam ke Mekah. 
POLITICON : Jurnal Ilmu Politik Vol.2 No.1; Hal.1- 12

Website : http://journal.uinsgd.ac.id/index.php/politicon

ISSN : 2685-6670 ( Online )

\section{KEPENTINGAN MEMAHAMI MAQASID KEAMANAN DAN KESANNYA}

Maqasid perdamaian adalah manifestasi dari maqasid syariah yang memelihara aspek-aspek penting untuk kepentingan umat manusia. Dengan demikian, Maqasid Syariah adalah pengetahuan yang harus dipahami umat Islam agar setiap hal yang harus dipenuhi dapat dibedakan antara persyaratan (al-dharuriyyat), kehendak (al-hajiyat), dan kesempurnaan (al-tahsiniyat). Kedamaian termasuk dalam kategori kebutuhan (al-dharuriyyat) yang membawa banyak manfaat dan manfaat. 'Alal al-Fasi (Al-fasi, 1963) menyatakan bahwa sebagian besar ulama secara eksplisit menekankan bahwa perdamaian universal adalah tujuan sekularisme yang harus dipenuhi oleh umat Islam karena tujuan Islam adalah mencapai konsensus negara-negara untuk melarang pertumpahan darah dan menjaga perdamaian..

Menurut pandangan Abdullah Bayyah dalam Adam, Zulkarnain, \& Ramli (2018), ia mengaitkan perdamaian dengan kondisi yang dianggap bertanggung jawab atas penyembahan. Ini berarti bahwa ketika kehidupan manusia, properti dan keturunan dilindungi dan aman, mereka dapat melakukan ibadah dengan baik dan baik. Umat Islam perlu tahu bahwa hukum Islam selalu melindungi hak asasi manusia tanpa memandang agama (Jumaah, 2018).

Kedamaian dan kedaulatan bangsa dapat tercapai jika rakyat mampu hidup bersama dalam suasana cinta, harmoni dan damai. Oleh karena itu, keharmonisan hidup dalam masyarakat dan agama multiras (al-Ta'ayush alSilmi) adalah kunci untuk pencapaian maqasid perdamaian dan untuk membimbing negara menuju stabilitas dan kemajuan politik. Ketika orang mampu mempraktekkan toleransi, keberanian, dan rasa hormat satu sama lain terlepas dari perbedaan pandangan, bangsa dan agama, maka harmoni dapat dirasakan dan perdamaian dapat dinikmati.

Melalui konsep perdamaian juga, suatu negara akan dapat membuat kemajuan yang baik dalam hal hubungan ekonomi, administrasi, pendidikan dan internasional yang merupakan komponen dari pembangunan peradaban 
POLITICON : Jurnal Ilmu Politik Vol.2 No.1; Hal.1- 12

Website : http://journal.uinsgd.ac.id/index.php/politicon

ISSN : 2685-6670 ( Online )

(Mohd Anuar, 2018). Pembangunan peradaban memakan waktu lama dan membutuhkan upaya semua pihak, termasuk individu, masyarakat, dan pemimpin. Perdamaian, keharmonisan kehidupan, dan stabilitas politik harus diberi tepuk tangan dan dijaga agar kemajuan negara dapat dicapai dan pembangunan peradaban yang agung diwujudkan. Ini semakin memperkuat fakta bahwa agama adalah faktor kunci dalam kualitas pencapaian peradaban. Ini menekankan prinsip-prinsip apresiasi nilai-nilai manusia untuk menentukan kualitas manusia di tingkat individu dan kolektif (Osman, 2017).

Kita dapat mengatakan bahwa keberhasilan umat Islam dalam membangun peradaban di Andalusia dan di seluruh dunia mencerminkan prinsip-prinsip yang ditetapkan oleh Utusan Allah di Madinah. Andalusia tidak berdiri sendiri di ruang kosong, itu adalah hasil dari kompilasi tradisi keunggulan yang akarnya bersifat Islam dan yang dukungannya adalah Tauhid (Muammar, 2009) Di sini dapat dikatakan bahwa peradaban besar Islam dibangun di atas penerapan nilai-nilai Islam murni termasuk nilai-nilai perdamaian dan keamanan. Islam adalah agama yang damai, damai dan menolak segala permusuhan dan perang. Ini dibuktikan dengan perjanjian perdamaian Hudaibiyyah antara Nabi (damai dan berkah Allah besertanya) dan Muslim Mekah pada tahun keenam Hijrah sekitar 628 M (Nasruddin, 2016).

Ada lebih banyak bukti dari kepala Nabi Muhammad tentang negosiasi yang dilakukan oleh Nabi untuk menjaga keharmonisan dan mencegah pertumpahan darah dan pertumpahan darah. Ibn Khaldun (1995) berpendapat bahwa di antara faktor-faktor internal runtuhnya peradaban adalah runtuhnya semangat așabiyyah, pembentukan terlalu banyak kelompok aṣabiyyah, tirani dan ketidakadilan sosial, penindasan kesadaran keagamaan dan ketidakstabilan politik serta kelemahan pemerintah. Ibn Khaldun (1995) juga memperkenalkan konsep tirani (zulm) dan ketidakadilan. Dalam pandangannya, prevalensi ketidakadilan dan ketidakadilan adalah kontributor utama runtuhnya peradaban karena ia 
POLITICON : Jurnal Ilmu Politik Vol.2 No.1; Hal.1- 12

Website : http://journal.uinsgd.ac.id/index.php/politicon

ISSN : 2685-6670 ( Online )

percaya bahwa ketidakadilan dan ketidakadilan menghancurkan perkembangan kecerdasan manusia baik secara fisik maupun mental, sehingga membunuh semangat hidup (Maslan \& Shamsudin, 2016). Tirani pemerintah dan ketidakstabilan politik adalah salah satu penyebab paling sulit dari keharmonisan hidup dan akan mengundang kekacauan dan kedamaian.

\section{SIMPULAN}

Islam adalah agama yang didasarkan pada Al-Quran dan Sunnah. Tidak ada ajaran Islam yang menyerukan para pengikutnya untuk memancing permusuhan dan bahkan membawa kekacauan dan perang. Dalam pandangan yurisprudensi Islam maqasid yang juga menguraikan pelestarian jiwa, pernyataan bahwa Islam adalah agama teror dan bahwa hal itu dianggap sebagai penyebab kematian manusia adalah kesalahpahaman kerangka Islam itu sendiri.

Keharmonisan, kedamaian dan kedamaian adalah hal mendasar bagi agama suci ini. Jika api rasial, kepekaan agama, perbedaan dalam kesadaran politik tidak terdokumentasi dengan baik, keharmonisan kehidupan dalam masyarakat bisa sulit dicapai dan pada akhirnya membawa kesengsaraan universal dan kehancuran yang tak terbayangkan.

\section{DAFTAR PUSTAKA}

Abdullah, B. (1999). Khitab al-Amn fi al-Islam wa Thaqafat al-Tasamuh wa alWi'am. Arab Saudi: Akadimiyah Nayif al'Arabiyah li al-'Ulum al-Amaniah. Adam, F. K., Zulkarnain, S. I. N. M., \& Ramli, M. A. (2018). Pandangan Shaykh Abdullah Bin Bayyah Tentang Konsep Keamanan: Kajian Terhadap Buku Khitab Al-Amni Fi Al-Islam. Jurnal Peradaban, 11, 86-114.

Al-fasi, A. (1963). Maqasid al-Syariah al-Islamiah Wa Makarimuha. Rabat. Al-Isfahani, A.-R. (1992). Mufradat Alfaz Al Quran. Dar Al-Qalam (Damascus). Al-Qaradawi, Y. (2009). Fiqh al-Jihad. Kairo: Maktabah Wahbah.

Al-Raisuni, A. (2018). Maqsad al-Salam fi al-Syariah al-Islam. Kaherah: Buruj Books.

Arsyad, Dea. (2019). Rivalitas Purnawirawan Jenderal Militer dalam 
POLITICON : Jurnal Ilmu Politik Vol.2 No.1; Hal.1- 12

Website : http://journal.uinsgd.ac.id/index.php/politicon

ISSN : 2685-6670 ( Online )

Pemilihan Presiden 2019. Politicon, 1(2), 158-175.

https://doi.org/10.15575/politicon.v1i2.5963

Ashur, I., \& 'Asyur, M. T. (2018). Maqasid al-Syari'ah al-Islamiyyah. Beirut: Dar Al-Salam.

Azhar, A., Hussain, M. A., Nor, M. Z. M., \& Othman, M. K. (2017). Penyelidikan

Fatwa Dalam Kerangka Maqasid Al-Syariah: Satu Tinjauan. Ulum Islamiyyah, 20, 47-65.

Azhar, A., Othman, M. K., Hussain, M. A., \& Md Nor, M. Z. (2017). Penyelidikan Fatwa Dalam Kerangka Maqasid Al-Syariah.

Bakar, O. (2017). Malaysia dari Perspektif Ketamadunan: Sebuah Inspirasi dari Ibnu Khaldun. Jurnal Peradaban, 4, 1-18.

Hidayatulloh, M. K. (2018). Konsep Dan Metode Tafsir Tematik (Studi Komparasi Antara Al-Kumi Dan Mushthofa Muslim). Al-Bayan: Jurnal Studi Ilmu Al-Qur'an Dan Tafsir, 3(2).

Jumaah, A. (2018). Al-Ta'ayush Ma'a Al-Akhar Fi Dhau' Al-Sirah Al-Nabawiyyah Al-Usus wa Al-Maqasid. Kaherah: Buruj Books.

Leonard, L. (2015). Kajian peran konsistensi diri terhadap prestasi belajar matematika. Formatif: Jurnal Ilmiah Pendidikan MIPA, 3(2).

Maslan, A., \& Shamsudin, R. (2016). Kejatuhan Pemerintahan Menurut Pemikiran Ibn Khaldūn dalam Karyanya al-Muqaddimah. Jurnal Akidah \& Pemikiran Islam, 18, 89-114.

Masruri, U. N. (2016). Pelestarian Lingkungan dalam Perspektif Sunnah. AtTaqaddum, 6(2), 411-428.

Muammar, K. (2009). Faktor kegemilangan tamadun Islam: pengajaran dari masa lalu. Jurnal Hadhari, 1(2), 15-31.

Nasruddin, N. (2016). Sejarah Peradaban Islam: dari Muhammad SAW sampai Turki Ustmani. Gunadarma Ilmu.

Rahim, R. A. A., Ramli, M. A., \& Zulkepli, M. I. S. (2018). Gejala Takfirisme Dalam Gerakan Ekstremisme Agama Semasa. Jurnal Peradaban, 11, 43-61.

Sugiyono. (2013). Metode Penelitian Pendidikan Pendekatan Kauntitatif, 
POLITICON : Jurnal Ilmu Politik Vol.2 No.1 ; Hal.1- 12

Website : http://journal.uinsgd.ac.id/index.php/politicon ISSN : 2685-6670 ( Online )

kualitatif dan R\&D. Bandung: Alfabeta.

Copyright (c) 2020 Muhammad Talhah Ajmain@Jimaain et.all

This work is licensed under a Creative Commons Attribution-

ShareAlike 4.0 International License. 